\title{
EXPRESSION LEVEL OF Sh2 AND Bt2 GENES IN SOME ADVANCED CORN LINES UNDER TROPICAL ENVIRONMENT
}

\author{
F. Abna ${ }^{1 *}$, F. A. Avin ${ }^{2}$ and N. W. Haron ${ }^{1 *}$ \\ ${ }^{1}$ Institute of Biological Science, Faculty of Science, University of Malaya, Kuala Lumpur, Federal Territory of Kuala \\ Lumpur 50603, Malaysia \\ ${ }^{2}$ Otis L. Floyd Nursery Research Center, 472 Cadillac Lane, McMinnville, Tennessee 37110, USA \\ Corresponding Author Email: fatemehabna@yahoo.com, farhat.avin@gmail.com, noorma@um.edu.my
}

\begin{abstract}
The rate-limiting step in starch synthesis entails the synthesis of ADP-Glc from Glc-1-P and ATP by AGPase. AGPase is a heterotetramer composed of two large subunits encoded by Sh2 and two small subunits encoded by Bt2. We examined the transcript level of each gene that encodes AGPase through quantitative real-time PCR (qRT_PCR) within endosperm and leaf tissues from 6 newer composite corn lines. The Sh2 and Bt2 genes presented upregulated expression levels in leaf and endosperm tissue. The highest expression level of these two genes in leaf tissues was observed in UM 1 with 6.96 fold and in UM 11 with 3.94 fold respectively. Meanwhile, the highest transcript level of Sh2 and Bt2 genes in endosperm tissues were observed in UM 2 with 5.96-fold and UM 1 with 7.36 fold respectively. The correlation coefficient between the expression levels of the Sh2 gene and the morphological traits in endosperm tissue indicated that it was significantly and positively correlated with ear length (0.75), ear weight (0.74) and yield (0.66). Meanwhile, the correlation coefficient results indicate that the expression level of Bt2 in endosperm tissue was significantly and positively correlated with 1000 kernel weight $(0.93)$, yield (0.90), ear weight $(0.87)$ and ear length (0.87). In conclusion, via cross transformation approaches, two main yield-related genes ( $S h 2$ and $B t 2)$ were modified in the new advanced corn lines. Overexpression of $S h 2$ and Bt2 genes can increase the starch content through enhancing the activity of AGPase and subsequently the yield enhancement occurred.
\end{abstract}

Keywords: crossbreeding, gene modification, maize yield, ADP-glucose pyrophosphorylase.

https://doi.org/10.36899/JAPS.2020.2.0048

Published online March 02, 2020

\section{INTRODUCTION}

Maize is among the most important crops as its kernels afford huge amounts of starch content, a carbohydrate derived from variable proportions of amylopectin and amylose polymers. Similarly, maize starch is a key industrial raw material in the production of various films and coatings, paper, textiles, medical instruments, biodegradable electronics and packaging, and first-generation biofuel products (Guan, Wang et al. 2011). The dedicated biosynthesis pathway of starch in corn endosperm involves coordinated activity by numerous enzymes, namely ADP-glucose pyrophosphorylase (AGPase), soluble starch synthase (SS), starch branching enzyme (SBE), granule-bound starch synthase (GBSS), plastidial starch phosphorylase (Pho1), and starch debranching enzyme (DBE) (Jeon, Ryoo et al. 2010). Plant ADP-glucose pyrophosphorylase (AGPase) catalyses inorganic pyrophosphate (PPi) and ADP-glucose (ADPGlc) generated from ATP and Glc-1$\mathrm{P}$, thereby producing the nucleotide sugars that are utilised by starch synthases to combine glucosyl units into starches. AGPase is a heterotetramer that comprises dual larger subunits (AGP-L) encoded via Shrunken2 $(S h 2)$ plus two smaller subunits (AGP-S) encoded via
Brittle2 (Bt2) (Hannah, Shaw et al. 2001). Expression of heat-stabilised corn AGPase with low inhibitory sensitivity to orthophosphates (HS33/Rev6 Sh2) raised grain yields for wheat by some $38 \%$ (Smidansky, Clancy et al. 2002) and also for rice yields by some $23 \%$ (Smidansky, Martin et al. 2003). Overexpression of wild types of Sh2 and Bt2 in corn increased kernel mass by 15 $\%$, which reflects the increased total starch content $(\mathrm{Li}$, Zhang et al. 2011). Expression of allosterically-modified AGPase also intensified turnover in transitory starches, resulting in improved growth in Arabidopsis thaliana leaf tissues (Obana, Omoto et al. 2006) as well as increased weight of fresh lettuce leaves (Lee, Ryu et al. 2009).

Some of the mutations in sweet corn are differing from field corn and cause the kernels to accumulate approximately two times more sugar more than field corn and significantly less starch. The level of the genes expression determines endosperm carbohydrate content is the primary difference as well as many other mutants that affect maize growth (Erdal, Pamukcu et al. 2011, Najeeb, Sheikh et al. 2011, Znidarcic 2012). Due to the genetic improvement maize kernels have been smaller in sweet corn than in field corn. Many researchers have tried to adapt the quality and quantity of starch content in plants via genetic engineering, typically through 
modulation of amylose-amylopectin ratios (Jiang, Yu et al. 2013). An increase of $12 \%$ in kernel mass was attained in some corn lines that were transformed via an AGPase with less sensitivity to orthophosphate inhibition (Giroux, Shaw et al. 1996). A brittle-2 transgene was expressed in the endosperm and the mutant endosperm phenotype was complemented. The transgene increased yield by enhancing the probability that an ovary developed into a functional kernel (Hannah, Shaw et al. 2017).

In this study, six high yield potential corn varieties with superior nutritive and free sugar were developed. We monitored overexpression of Sh2 and Bt2 genes and their relationship with yield and yield components in advanced corn lines to overcome the low productivity in sweet corn and low nutritive values in field corns. The presence of Sh2 and Bt2 genes were detected in new UM composite corn lines. The effect of hybridisation on the transcript levels of $S h 2$ and Bt2 genes in leaf and endosperm tissues was estimated using quantitative real-time PCR (qRTPCR).

\section{MATERIALS AND METHODS}

Plant materials: In this research, 12 corn advance lines were gathered from the Institute of Biological Sciences (ISB), University of Malaya, Malaysia. The 12 best cross hybrids were derived from yellow sweet as well as white field maize. Parental field maize was gathered at the International Maize and Wheat Improvement Centre (CIMMYT), Mexico, while parental sweet maize was gathered at the International Institute of Tropical Agriculture (IITA, Nigeria). Initially, all of these twelve lines were grown for morph-agronomic evaluation at the tropical environment (Malaysia) and also were screened to presence of $S h 2$ and $B t 2$ genes, finally based on the morphological performance and their physio-chemical performance like $\mathrm{pH}$, total soluble solids, protein, fat, total sugars, and starch content, six outstanding lines were selected for gene expression analysis.

DNA and RNA extraction: The complete genomic DNA of all maize plants was drawn from $100 \mathrm{mg}$ of new leaf tissues gathered from each type, using the DNeasy Plant Mini Kit. As well, these plant leaf collections were preserved and stored using liquid nitrogen at a temperature of $-80^{\circ} \mathrm{C}$. RNA was extracted from the endosperm and leaf tissues of 6 corn advance lines. The total leaf RNA isolate was extracted with an RNA extraction kit, the SV Total RNA Isolation System (Promega, USA). Total endosperm RNA isolate was extracted from the dissected mid-ear endosperm 20 days after pollination (DAP), representing the interval of active starch 'filling' (Shang-Jing, Jia-Rui et al. 2006), with the use of Trizol Reagent (Invitrogen), following manufacturer protocol. The total RNA is pooled from 3 individual kernels taken from each ear.

Polymerase Chain Reaction (PCR) and Sequencing of genomic DNA: The polymerase chain reaction (PCR) amplification for all primer sets were carried out using the $\mathrm{C} 1000$ Thermal Cycler (Bio-Rad) within a reaction solution of $10 \mu$ l total volume, which consisted of $1.5 \mu \mathrm{l}$ of DNA drawn from leaf tissues, $5 \mu$ l of Gotaq Green master blend (Promega, USA), and also $1 \mu \mathrm{l}$ from every primer $(10 \mathrm{mM})$. PCR reactions were conducted in the following manner: initial denaturation was conducted at $95^{\circ} \mathrm{C}$ for 5 minutes, and then 35 cycles of denaturation were carried out at a temperature of $94^{\circ} \mathrm{C}$ for 30 seconds, with annealing temperatures for 30 seconds, including a 1 minute extension step at a temperature of $72^{\circ} \mathrm{C}$. This programme was concluded with a final step conducted at a temperature of $72{ }^{\circ} \mathrm{C}$ for 10 minutes. After amplification, the incidence of PCR product was verified using electrophoresis. A $1.0 \%$ agarose gel was utilised for the electrophoresis of PCR product. Gel electrophoresis was conducted at levels of 80 volts, $175 \mathrm{~mA}$, utilising a 1 $x$ TBE running buffer for an interval of 30 minutes. All gels were visualised under ultraviolet lighting (Alpha Imager Gel Documentation System, Siber Hegner, Germany). Similarly, sequencing product was analysed using the ABI 3730xl DNA analyser (Applied Biosytems, USA).

Real-Time PCR: The Real time quantitative PCR amplification was done for extracted RNA samples from leaf and endosperm tissues of six corn advance lines. Real time quantitative PCR amplification was conducted with use of CYBR green fluorescence via RTqPCR (CFX96 Touch $^{\mathrm{TM}}$ Real-Time PCR Detection System, Bio-Rad, USA) on a reaction volume of $20 \mu \mathrm{l}$ in total, which consisted of SYBR Green blend (GoTaq 1-step RTqPCR reaction mix, Promega, USA), primer (reverse and forward), nuclease-free water, and also RNA template $(100 \mathrm{ng})$, with negative control (absent reverse transcriptase). Neither template (no RNA) nor Positive (no primer) controls were involved in the reaction sets, which were each assayed in triplicate for 3 biotic replicates. Thermal cycling conditions were set at a temperature of $48^{\circ} \mathrm{C}$ for 15 minutes (Reverse transcription), at $95^{\circ} \mathrm{C}$ for 10 minutes (Reverse transcription inactivation), prior to 40 cycles at $95^{\circ} \mathrm{C}$ for 10 seconds (Denaturation), then at $58^{\circ} \mathrm{C}, 52^{\circ} \mathrm{C}$, and $55^{\circ} \mathrm{C}$ corresponding to $18 \mathrm{~s}, \mathrm{Bt} 2 \mathrm{~b}$ and $\mathrm{Sh} 2$ for 30 seconds (Annealing), at $72^{\circ} \mathrm{C}$ for 30 seconds (Extension). Following amplification, all samples were stored at a temperature of $95^{\circ} \mathrm{C}$ for 10 seconds and at $65^{\circ} \mathrm{C}$ for 5 seconds, which was gradually increased by $0.5^{\circ} \mathrm{C}$ every 5 seconds to acquire the melt curves (Cholet, Ijaz et al. 2018). 
Statistical analysis: Quantifications of gene expressions were conducted based on the relative quantification methods developed by (Livak and Schmittgen 2001). Pearson correlation coefficients were used to investigate the relationship between morphological traits and molecular data. To compare the relative transcript level of $S h 2$ and $B t 2 b$, one-way analysis of variance was used and mean comparison was done using Duncan multiple range test.

\section{RESULTS}

Successful amplification of DNA isolated from the corn advance lines: The average DNA concentration obtained was $0.6 \mu \mathrm{g} / \mu \mathrm{l}$ with purity of A260/280 1.80 for each corn line. The polymerase chain reaction (PCR) assay using gene-specific primers showed that the Sh2 gene, a transcript of the $B t 2$ gene $(B t 2 b)$ and $18 \mathrm{~s}$ gene could be amplified from DNA isolated using the DNeasy Plant Mini Kit (Fig. 1). However, another transcript of
Bt2 (Bt2a) could not be amplified with the DNA isolated from these corn advance lines. Based on these results, a quantitative real-time PCR was performed to find the expression level of each of these two genes in the UM composite corn lines.

Relative transcript level of the $S h 2$ and $B t 2 b$ genes in the leaf tissue of six corn advance lines: To study the relative expression of the $S h 2$ and $B t 2 b$ genes, the $18 \mathrm{~s}$ gene was used as an internal control and the parent line of each corn advance line served as a calibrator. The calibrators demonstrated a unique fold (almost 1.00) measurement, while the Sh2 and $B t 2 b$ genes demonstrated different expression levels in the leaf tissue at each location. The $B t 2 b$ gene presented upregulate expression levels in the leaf tissue of all six corn advance lines (Fig. 2). The highest expression level of the $B t 2 b$ gene was observed for UM 11 with 3.94 fold, followed by UM 3 (3.36), UM 6 (3.32), UM 4 (2.84) and UM 1 (2.21). The lowest expression level of the $B t 2 b$ gene was seen for UM 2 with 1.76 fold.

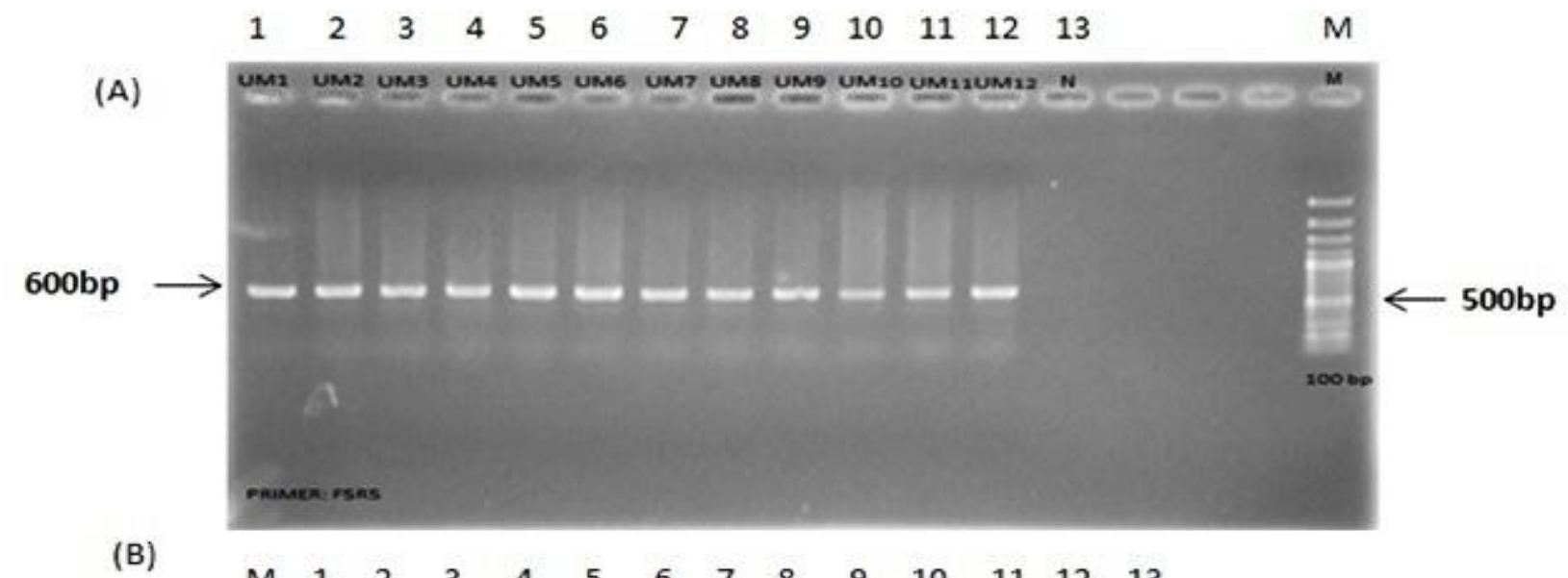

(B)
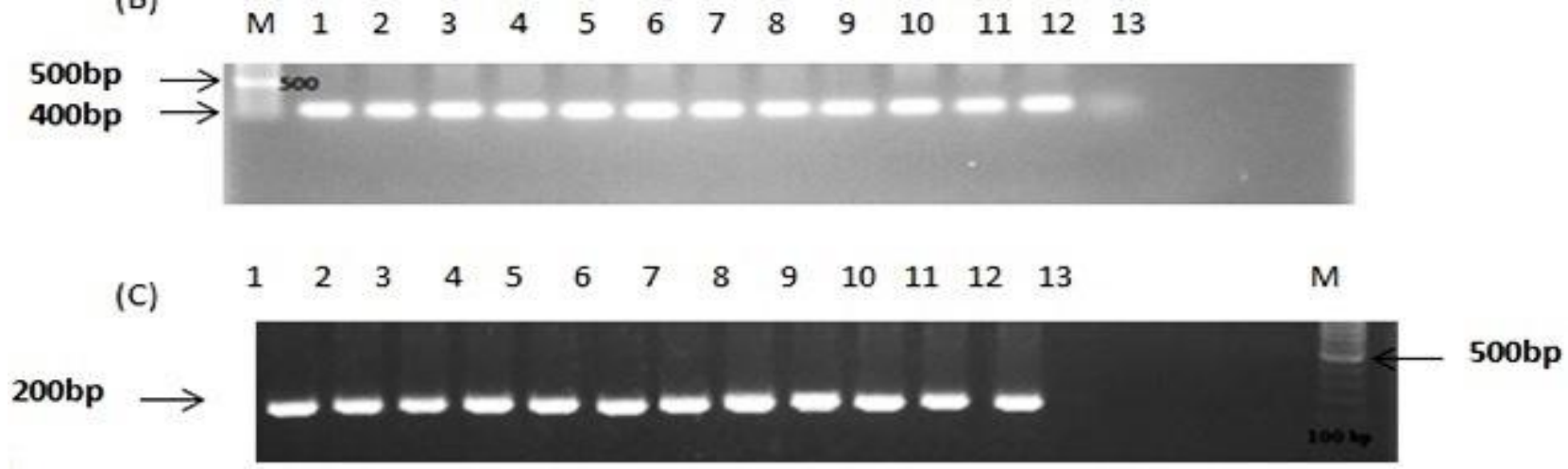

Figure 1. Screening of corn advanced lines for $S h 2, B t 2 b$ and $18 s$ genes by PCR. (A) Amplified fragments using F5R5-Fw and F5R5-Re primer set corresponding to $S h 2$ gene. Lane 1-12: corn advanced lines carrying Sh2 gene. Lane 13: Negative control for PCR reaction. M: DNA marker (Promega). The size of each product is indicated to the left of the gel. (B) 400 bp amplicon size using Bt2-Fw and Bt2-Re primer set corresponding to $B t 2 b$ gene. Lane 1-12: corn advanced lines carrying $B t 2 b$ gene. Lane 13: Negative control for PCR reaction. M: DNA marker (Promega). (c) 200 bp amplicon size using 18s-Fw and 18s-Re primer set corresponding to $18 \mathrm{~s}$ gene. Lane 1-12: corn advanced lines carrying 18s gene. Lane 13: Negative control for PCR reaction. M: DNA marker (Promega). 


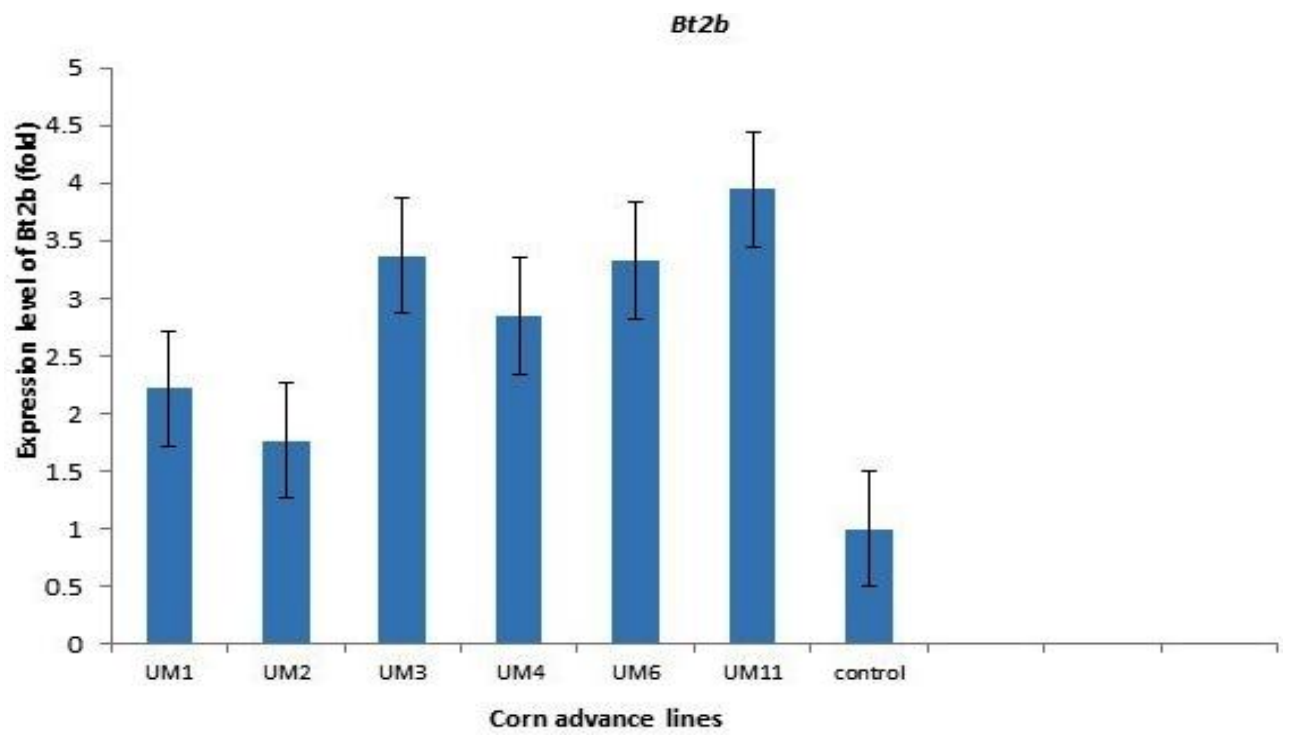

Figure 2. Relative transcript level of $B t 2 b$ gene in leaf tissue of six corn advance lines.

The relative transcription levels of the $S h 2$ gene presented upregulation in the leaf tissue of all six corn advance lines. The highest expression level of the Sh2 gene was observed in UM 1 with 6.96 fold, followed by
UM 4 (6.29), UM 11 (6.11), UM 6 (5.74) and UM 2 (5.32). The lowest expression level of the $S h 2$ gene was seen in UM 3 with 4.54 fold, as presented in Fig. 3.

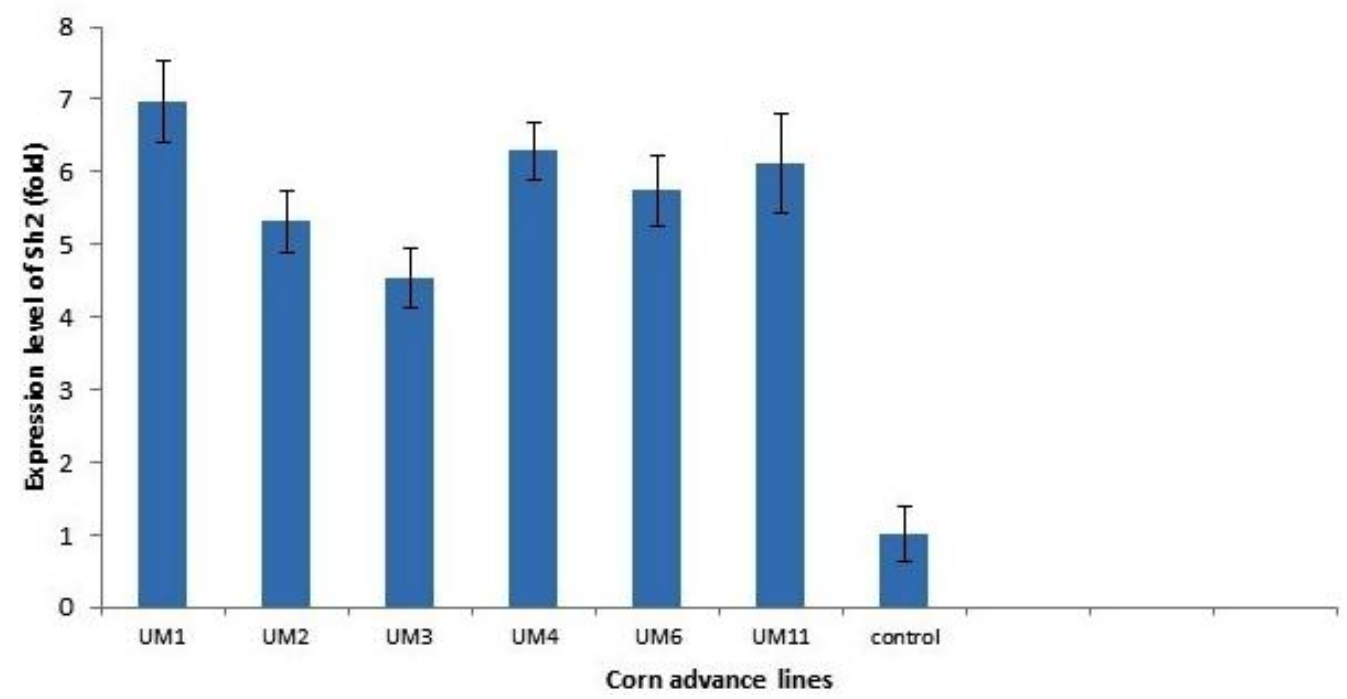

Figure 3. Relative transcript level of $S h 2$ gene in leaf tissue of six corn advance lines.

To compare the expression levels of the $B t 2$ and $\operatorname{Sh} 2$ genes in the leaf tissue of six corn lines, analysis of variance was done. The results show the variability of these two genes in different lines. The expression levels of the $B t 2$ gene displayed significant differences among the six corn advance lines. Significance was at the $p<0.05$ level among six corn advance lines. Meanwhile, the expression level of $S h 2$ showed significant differences at the $p<0.05$ level among six corn advance lines. Following the analysis of variance, Duncan's multiple range test was applied for a mean comparison among corn advance lines (Table 1). The mean comparison results indicate that the highest mean expression level of the $B t 2 b$ gene in leaf tissue belonged to UM 11 (4.11), which was significantly different from UM 1 and UM 2. Meanwhile, the highest mean expression level of Sh2 in leaf tissue belonged to UM 1 with 6.97 fold, whereby the Sh2 gene in UM 1 was significantly different from UM 3. 
Table 1. Mean comparison for expression level of $S h 2$ and $B t 2 b$ genes in leaf tissues among six corn advance lines at two test locations using Duncan's multiple range test.

\begin{tabular}{ccc}
\hline & Bt2b (Malaysia) & Sh2 (Malaysia) \\
\hline UM1 & $2.22 \pm 0.114 \mathrm{~b}$ & $6.97 \pm 0.028 \mathrm{a}$ \\
UM2 & $1.80 \pm 0.252 \mathrm{~b}$ & $5.33 \pm 0.178 \mathrm{ab}$ \\
UM3 & $3.37 \pm 0.081 \mathrm{ab}$ & $4.57 \pm 0.35 \mathrm{~b}$ \\
UM4 & $2.86 \pm 0.185 \mathrm{ab}$ & $6.38 \pm 0.755 \mathrm{ab}$ \\
UM6 & $3.33 \pm 0.071 \mathrm{ab}$ & $5.77 \pm 0.396 \mathrm{ab}$ \\
\hline
\end{tabular}

Relative transcript levels of the $\operatorname{Sh} 2$ and $B t 2 b$ genes in the endosperm tissues of six corn advance lines: To study the relative expression of the $S h 2$ and $B t 2 b$ genes, the $18 \mathrm{~s}$ gene was used as internal control and the parent line of each advance line served as a calibrator. The calibrators demonstrated a unique fold (almost 1.00) measurement, while the $S h 2$ and $B t 2 b$ genes demonstrated different levels of expression in the endosperm tissue at each location. The $B t 2 b$ gene presented upregulated expression levels in the endosperm tissue of all six corn advance lines (Fig. 4). The highest expression level of $B t 2 b$ was observed in UM 1 with 7.36 fold, followed by UM 3 (6.04), UM 11 (5.89), UM 2 (5.43) and UM 6 (5.15). The lowest expression level of $B t 2 b$ was observed in UM 4 with 3.93 fold for this line (Fig. 4).

In the endosperm tissue of the six corn advance lines, the relative transcription levels of the Sh2 gene presented upregulation (Fig. 5). The highest expression level of Sh2 was observed in UM 2 with 5.96 fold, followed by UM 6 (5.2), UM 4 (4.44), UM 11 (4.21) and UM 3 (4.18). The lowest expression level of Sh2 was observed in UM 1 with 3.12 fold, as presented in Fig. 5. A comparison of the relative transcription levels in the
$B t 2 b$ and $S h 2$ genes indicates that the expression levels of $B t 2 b$ in the endosperm tissue of all six corn advance lines were in a higher range than the transcription levels of Sh2.

To compare the expression levels of the $B t 2$ and Sh2 genes in the endosperm tissue of six corn lines, an analysis of variance was done. The results indicate variability in different corn advance lines. The expression levels of the $B t 2$ gene were significantly different among the six corn advance lines. Significance was at the $p<0.05$ level for six corn advance lines. While the expression level of $S h 2$ showed significant differences at the $p<0.01$ level among six corn advance lines. Following the analysis of variance, Duncan's multiple range test was used for a mean comparison among corn advance lines (Table 2). The mean comparison results for the corn advance lines indicate that the highest mean expression level of the $B t 2 b$ gene in endosperm tissue was found in UM 1 (7.46), which was significantly different from UM 4. Meanwhile, the highest mean expression level of the Sh2 gene in the endosperm tissue of the corn advance lines was obtained for UM 2 (5.99) and it was significantly different from UM 1, UM 3, UM 4 and UM 11.

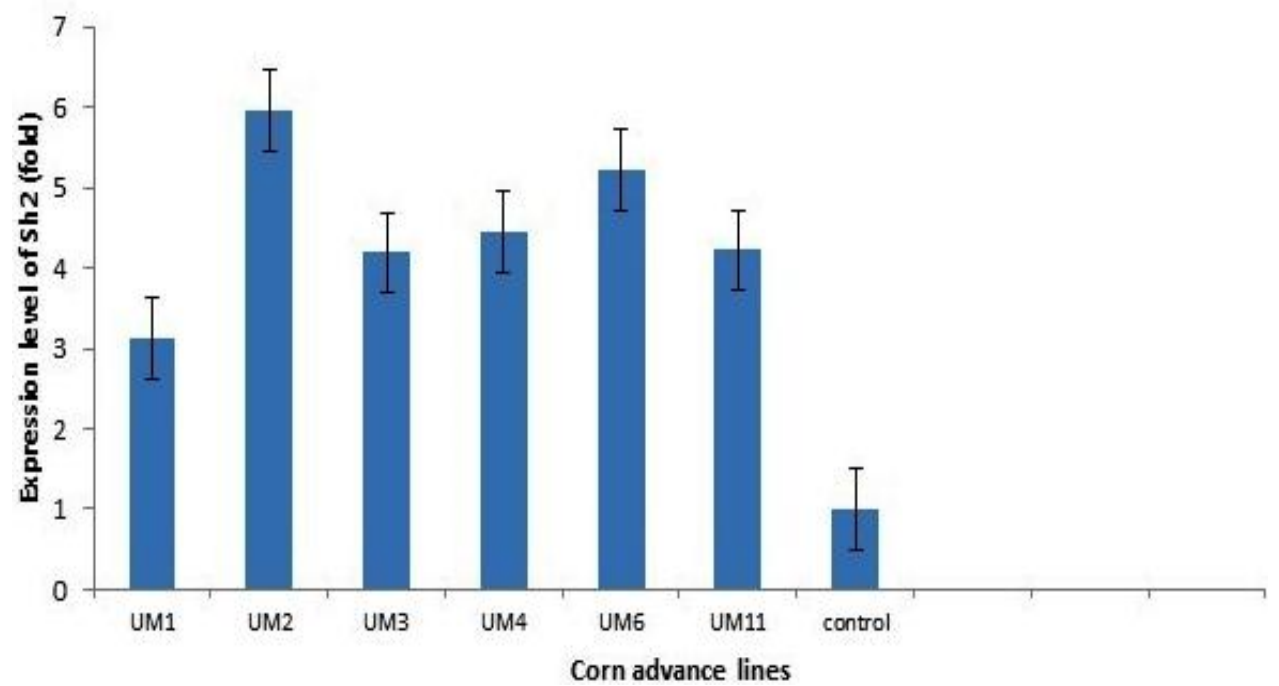

Figure 4. Relative transcript level of $B t 2 b$ gene in endosperm tissue of six corn advance lines 


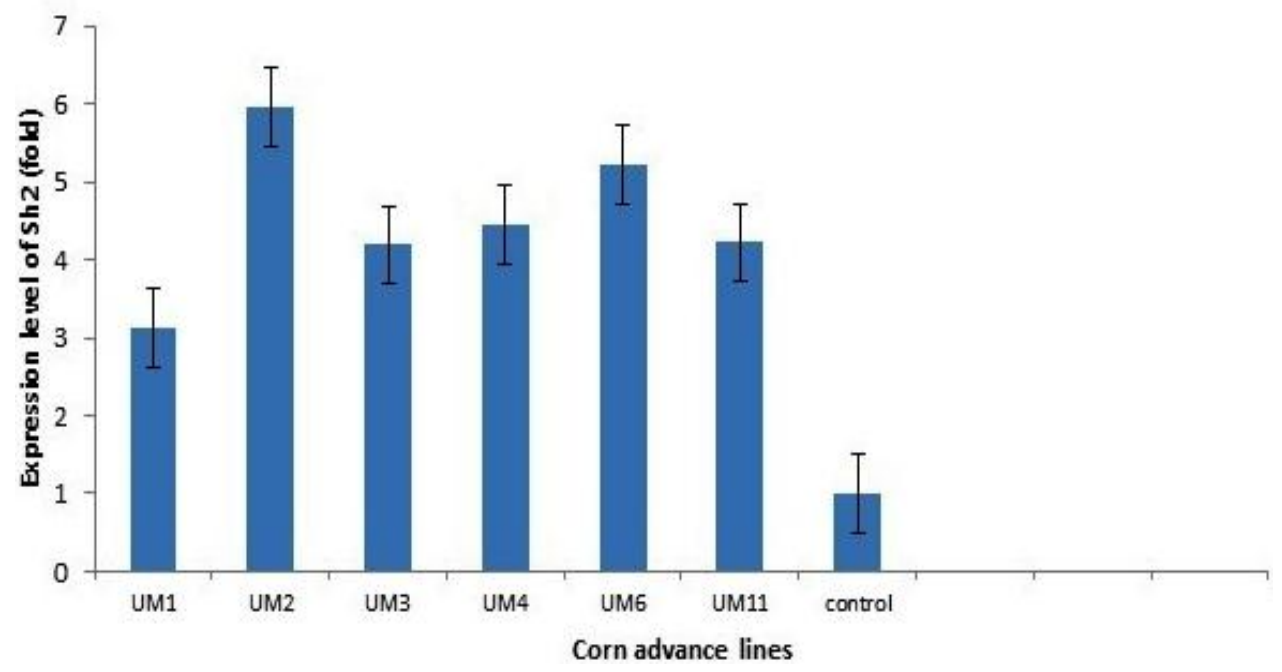

Figure 5. Relative transcript level of $\operatorname{Sh} 2$ gene in endosperm tissues of six corn advance lines

Table 2. Mean comparison for expression level of $S h 2$ and $B t 2$ genes in endosperm tissues among six corn advance lines using Duncan's multiple range test.

\begin{tabular}{ccc}
\hline & Bt2b (Malaysia) & Sh2 (Malaysia) \\
\hline UM1 & $7.46 \pm 0.873 \mathrm{a}$ & $3.15 \pm 0.264 \mathrm{c}$ \\
UM2 & $5.45 \pm 0.3 \mathrm{ab}$ & $5.99 \pm 0.372 \mathrm{a}$ \\
UM3 & $6.05 \pm 0.074 \mathrm{ab}$ & $4.19 \pm 0.058 \mathrm{bc}$ \\
UM4 & $4.00 \pm 0.497 \mathrm{~b}$ & $4.45 \pm 0.066 \mathrm{~b}$ \\
UM6 & $5.33 \pm 1.03 \mathrm{ab}$ & $5.26 \pm 0.494 \mathrm{ab}$ \\
UM11 & $5.91 \pm 0.272 \mathrm{ab}$ & $4.22 \pm 0.064 \mathrm{bc}$ \\
\hline
\end{tabular}

According to the correlation coefficient results, the expression level of the $B t 2$ gene in leaf tissue showed a negative and non-significant correlation with all morphological traits except plant height (0.08) and 1000 kernel weight (0.02) (Table 3 ). The expression level of the $S h 2$ gene in leaf tissue also showed a non-significant correlation with all morphological traits, but it had a positive correlation with the ear number per plant, ear weight, and ear length, kernel number per ear, 1000 kernel weight and yield. Meanwhile, the correlation coefficient results indicate that the expression level of Bt2 in endosperm tissue was significantly and positively correlated with ear number per plant (0.69), ear weight (0.87), ear length (0.87), kernel number per ear (0.75), 1000 kernel weight $(0.93)$ and yield $(0.90)$ at the $p<0.01$ level. The results also indicate that with increasing expression level of the $B t 2$ gene in endosperm tissue, the ear number per plant, ear weight, ear length, kernel number per ear, 1000 kernel weight and yield increased. However, the expression level of the Bt2 gene in endosperm tissue showed negative and significant correlations with tasseling date $(-0.69)$, silking date (0.72 ) and plant height (-0.92). Moreover, the correlation coefficient results indicate that the expression level of
Sh2 in endosperm tissue was significantly and positively correlated with ear weight $(0.74)$, ear length $(0.75)$ and 1000 kernel weight $(0.71)$ at the $\mathrm{p}<0.01$ level, while it was significantly and positively correlated with ear number per plant $(0.63)$ and yield $(0.66)$ at the $p<0.05$ level for both locations. According to the results, with increasing expression levels of the Sh2 gene in endosperm tissue, the ear number per plant, ear weight, ear length, 1000 kernel weight and yield increased. In this study, the expression level of the Sh2 gene was upregulated in leaf and endosperm tissue via a hybridization program. Using the transgenic technique will significantly increase the expression level of this yield-related gene. The expression level of Sh2 in endosperm tissue showed negative and significant correlations with tasseling date $(-0.89)$, silking date ($0.79)$ and plant height (-0.70). Based on the correlation results, increasing the tasseling date, silking date, and plant height significantly decreased the expression levels of the Bt2 and $S h 2$ genes in endosperm tissue. Hence, it seems logical to select short plant stature with short periods of anthesis and silking to express high levels of Bt 2 and $S h 2$ genes in endosperm tissue. 
Table 3. Correlation coefficient between expression level of $S h 2$ and $B t 2$ genes and morphological traits among six corn advance lines.

\begin{tabular}{lccccccccc}
\hline & $\begin{array}{c}\text { Tasselling } \\
\text { Date }\end{array}$ & $\begin{array}{c}\text { Silking } \\
\text { date }\end{array}$ & $\begin{array}{c}\text { Plant } \\
\text { height }\end{array}$ & $\begin{array}{c}\text { Ear } \\
\text { no.plant }\end{array}$ & $\begin{array}{c}\text { Ear } \\
\text { wtg }\end{array}$ & $\begin{array}{c}\text { Ear } \\
\text { length }\end{array}$ & $\begin{array}{c}\text { No. } \\
\text { kernel } \\
\text { per ear }\end{array}$ & $\begin{array}{c}\text { 1000 } \\
\text { kernel } \\
\text { WT }\end{array}$ & Yield \\
\hline Bt2 (Leaf) & -0.057 & -0.14 & 0.08 & -0.18 & -0.04 & -0.06 & -0.08 & 0.02 & -0.17 \\
Bt2 (Endosperm) & $-0.69^{*}$ & $-0.72^{* *}$ & $-0.92^{* *}$ & $0.69^{*}$ & $0.87^{* *}$ & $0.87^{* *}$ & $0.75^{* *}$ & $0.93^{* *}$ & $0.90^{* *}$ \\
Sh2 (Leaf) & -0.08 & -0.278 & -0.28 & 0.243 & 0.44 & 0.45 & 0.38 & 0.31 & 0.33 \\
Sh2 (Endosperm) & $-0.89^{* *}$ & $-0.79^{* *}$ & $-0.70^{*}$ & $0.63^{*}$ & $0.74^{* *}$ & $0.75^{* *}$ & 0.55 & $0.71^{* *}$ & $0.66^{*}$ \\
\hline
\end{tabular}

* Correlation is significant at $\mathrm{p}=0.05$ level (2-tailed).

** Correlation is significant at $\mathrm{p}=0.01$ level (2-tailed).

In general, the detection and expression of two important yield-related genes ( $S h 2$ and $B t 2)$ in leaf and endosperm tissue were done by polymerase chain reaction and real-time PCR. The screening results indicate that the $S h 2, B t 2$, and $18 s$ genes were amplified by the gene-specific primers. The expression levels of Sh2 and Bt2 in leaf and endosperm tissue were upregulated in new advance corn lines. The upregulation of these $S h 2$ and $B t 2$ yield-related genes increases the starch synthesised in new advance corn lines. Accordingly, in this study increased starch and grain yield were obtained due to genetics.

An analysis of the relationships between the corn lines' morpho-agronomic variability and expression levels of the $S h 2$ and $B t 2$ genes in leaf and endosperm tissue revealed that some of the traits were significantly and strongly correlated with the expression level of $S h 2$ and $B t 2$ in endosperm tissue. Therefore, with improved breeding programs based on these traits, it is possible to increase the expression levels of these two yield-related genes.

\section{DISCUSSION}

This study clarifies the expression levels of shrunken-2 (Sh2) and brittle-2 (Bt2) genes that encode the large and small subunits of ADP-glucose pyrophosphorylase in the leaf and endosperm tissue of UM corn advance lines, respectively. Initially, six primer pairs were tested to amplify the Sh2 gene. Most of these six loci failed to amplify the genomic DNA of at least one of the corn advance lines or provided irreproducible banding patterns and were subsequently rejected. Among four designed primers and two published primers used to amplify the Sh2 gene, the F5R5 primer set successfully amplified the genomic DNA of twelve UM composite corn lines. Detecting the Sh2 gene with two published primers (LH71 and Sh2) generated multiple bands to amplify the Sh2 gene. Giroux (1996) reported using the LH71 primer to amplify DNA isolated from the leaves of Sh2 revertants, while (Huang, Hennen-Bierwagen et al. 2014) reported functions of multiple genes that encoded ADP-Glucose pyrophosphorylase subunits using the $S h 2$ primer to amplify the $S h 2$ gene in maize endosperm, embryo, and leaf. Since the $B t 2$ gene generates two transcripts referred to as $B t 2 a$ and $B t 2 b$ (Rosti and Denyer 2007), two primers were used to amplify the $B t 2 a$ and $B t 2 b$ transcripts. As shown in the result (Fig. 1) only one transcript of the $B t 2$ gene was amplified from the genomic DNA of composite corn lines. This might be related to the accumulation of the $B t 2$ gene in the embryo. Huang (2014) reported detecting the $B t 2 a$ transcript only in the endosperm, but Bt2a was not present in maize plant leaves. As a requirement to select a proper internal control gene, three housekeeping genes were tested including $18 \mathrm{~s}$, actin, and eEF1. From the results, it was observed that $18 \mathrm{~s}$ had the lowest CT value among the three housekeeping genes. Also in this investigation, the $18 \mathrm{~s}$ gene expressed uniformly in different corn lines, which led to using $18 \mathrm{~s}$ as internal control. Moreover, Huang (2014) reported using $18 s$ as a housekeeping gene for expression analysis in maize. To estimate the effect of hybridization and experimental treatment on the expression of an endogenous reference or internal control, the method proposed by Livak and Schmittgen (2001) was used. This method was also used to estimate the effect of hybridization on the target genes (Sh2 and Bt2). Endosperm mutations that include brittle2 (Bt2) and shrunken2 (Sh2) alter the starch pathway such that kernel sugars, particularly sucrose, accumulate in place of starch production. Zhang (2007) investigated and compared the relationships between the starch synthesis rates and the activities of enzymes responsible for starch biosynthesis in developing grains of normal, pop, sweet and waxy corn throughout the grain filling period (Zhang, Dong et al. 2007). Rate-limiting steps in starch synthesis involve ADP-Glc synthesised from Glc-1-P and ATP via AGPase (Russell, DeBoer et al. 1993). In this study, the $B t 2$ and $S h 2$ genes that encode the enzyme AGPase were selected. Their overexpression impact was investigated on the UM corn advance lines. According to Hannah (2012), the majority of attempts to improve starch accumulation in plants have emphasised on engineering AGPase activity (Hannah, Futch et al. 2012). The expression levels of $S h 2$ and $B t 2 b$ genes in newly developed UM corn advance lines were evaluated to 
consider the possibility of improving the starch content and increasing overall yield by multigene engineering. The results indicate that these two subunits of ADPglucose pyrophosphorylase (AGPase) were upregulated in the leaf and endosperm tissue of composite corn lines rather than their parental lines, whereas the gene-specific primer for $B t 2 a$ could not amplify the genomic DNA of these corn lines. The $B t 2 b$ transcript coding in plastidial isoforms was expressed in endosperm, leaf, and embryonic tissue, while $B t 2 a$, the conventional transcript coding in cytoplasmic isoforms, was favourably expressed in its developing endosperm (Cossegal, Chambrier et al. 2008, Huang, Hennen-Bierwagen et al. 2014).

The highest expression level of Sh2 in leaf tissues was observed in UM 1 among the six corn advance lines and the expression was 6.96 fold (Fig. 3). The upregulation of the Sh2 gene in 1000 kernel weight and yield per plant in UM 1 can be due to the positive correlation between the expression level of Sh2 and 1000 kernel weight and yield per plant (Table 3 ). The highest expression level of $B t 2 b$ in leaf tissue was observed in UM 11, with 3.94 fold (Fig. 2). The comparison of $B t 2 b$ and $S h 2$ gene expression levels indicates that the relative transcript level of Sh2 in the leaf tissue of all six corn advance lines was in a higher range than the transcript level of $B t 2 b$. As expected, $B t 2$ was weakly expressed in leaf tissues, but the strong expression was found in endosperm tissues, this result was agreed with Cossegal (2008) (Cossegal, Chambrier et al. 2008). The expression level of $B t 2 b$ also showed a negative correlation with yield per plant (Table 3 ). The results of comparing the expression level of $B t 2 b$ in endosperm tissue indicate that among six corn advance lines, the highest expression level was observed in UM 1 with 7.36 fold (Fig. 4). The upregulation of the $B t 2$ gene for 1000 kernel weight and yield per plant in UM 1 can be due to the significant and positive correlation between the expression level of Bt2 and 1000 kernel weight and yield per plant (Table 3 ). The results present the more impressive expression level of $B t 2 b$ in the endosperm of the six corn advance lines compared to the leaf of these lines.

The highest expression level of the $S h 2$ gene in the endosperm tissue of corn advance lines was observed in UM 2 with 5.96 fold (Fig. 5). According to the results, the $\operatorname{Sh} 2$ gene was strongly expressed in leaf tissue but moderately expressed in endosperm tissue. Based on the correlation results, increasing the tasseling period, silking period and plant height significantly decreased the expression levels of the Bt2 and $S h 2$ genes in endosperm tissue. Hence, it seems logical to select corn lines with short periods of anthesis and silking and the short plant stature to express high levels of $B t 2$ and $S h 2$ in endosperm tissue to increase the overall yield.
Conclusion: The transformation approach for crosses was used to produce new hybrid corn lines expressing two transgenes relevant to starch biosynthesis, specifically in leaf and endosperm tissue. From this study, the morpho-agronomic traits and evaluation of transcript levels of the $S h 2$ and $B t 2$ genes that encode the enzyme AGPase to enhance starch accumulation in plants and subsequently increase the overall maize yield provide a basis for plant breeding and crossbreeding programs. The composite corn lines obtained could be utilised for maize breeding programs in the future, in order to enhance the quality and quantity of starch content or produce modified starches for use in certain downstream applications. As future work, the expression level of $S h 2$ and $B t 2$ genes in the embryo of UM corn advance lines should be considered. More specifically, for the classical transcript $(B t 2 a)$, new gene-specific primers will be designed and the expression level of Bt $2 a$ in different tissues of corn advance lines will be measured. Besides, the expression level of the sugary genes in corn advance lines can be measured and compared with the parental lines.

Acknowledgement: We would like to thank University of Malaya for providing the research environment and facilities.

\section{REFERENCES}

Cholet, F., U. Z. Ijaz and C. J. Smith (2018). Differential amplicons for the evaluation of RNA integrity extracted from complex environmental samples. BioRxiv: 401109.

Cossegal, M., P. Chambrier, S. Mbelo, S. Balzergue, M.L. Martin-Magniette, A. Moing, C. Deborde, V. Guyon, P. Perez and P. Rogowsky (2008). "Transcriptional and metabolic adjustments in ADP-glucose pyrophosphorylase-deficient bt2 maize kernels." Plant Physiology 146(4): 15531570.

Erdal, Å., M. Pamukcu, O. Savur and M. Tezel (2011). "Evaluation of developed standard sweet corn (Zea mays sacharata L.) hybrids for fresh yield, yield components and quality parameters." Turkish J. Field Crops 16(2): 153-156.

Giroux, M. J., J. Shaw, G. Barry, B. G. Cobb, T. Greene, T. Okita and L. C. Hannah (1996). "A single mutation that increases maize seed weight." Proceedings of the National Academy of Sciences 93(12): 5824-5829.

Guan, S., P. Wang, H. Liu, G. Liu, Y. Ma and L. Zhao (2011). "Production of high-amylose maize lines using RNA interference in sbe2a." African J. Biotechnology 10(68): 15229-15237.

Hannah, L. C., B. Futch, J. Bing, J. R. Shaw, S. Boehlein, J. D. Stewart, R. Beiriger, N. Georgelis and T. 
Greene (2012). "A shrunken-2 transgene increases maize yield by acting in maternal tissues to increase the frequency of seed development." The Plant Cell 24(6): 2352-2363.

Hannah, L. C., J. R. Shaw, M. A. Clancy, N. Georgelis and S. K. Boehlein (2017). "A brittle-2 transgene increases maize yield by acting in maternal tissues to increase seed number." Plant Direct 1(6): e00029.

Hannah, L. C., J. R. Shaw, M. J. Giroux, A. Reyss, J.-L. Prioul, J.-M. Bae and J.-Y. Lee (2001). "Maize genes encoding the small subunit of ADPglucose pyrophosphorylase." Plant Physiology 127(1): 173-183.

Huang, B., T. A. Hennen-Bierwagen and A. M. Myers (2014). "Functions of multiple genes encoding ADP-glucose pyrophosphorylase subunits in maize endosperm, embryo, and leaf." Plant Physiology 164(2): 596-611.

Jeon, J.-S., N. Ryoo, T.-R. Hahn, H. Walia and Y. Nakamura (2010). "Starch biosynthesis in cereal endosperm." Plant physiology and Biochemistry 48(6): 383-392.

Jiang, L., X. Yu, X. Qi, Q. Yu, S. Deng, B. Bai, N. Li, A. Zhang, C. Zhu and B. Liu (2013). "Multigene engineering of starch biosynthesis in maize endosperm increases the total starch content and the proportion of amylose." Transgenic research 22(6): 1133-1142.

Lee, S.-M., T.-H. Ryu, S.-I. Kim, T. Okita and D. Kim (2009). "Kinetic and regulatory properties of plant ADP-glucose pyrophosphorylase genetically modified by heterologous expression of potato upreg mutants in vitro and in vivo." Plant Cell, Tissue and Organ Culture (PCTOC) 96(2): 161.

Li, N., S. Zhang, Y. Zhao, B. Li and J. Zhang (2011). "Over-expression of AGPase genes enhances seed weight and starch content in transgenic maize." Planta 233(2): 241-250.

Livak, K. J. and T. D. Schmittgen (2001). "Analysis of Relative Gene Expression Data Using RealTime Quantitative PCR and the $2<$ sup $>-$ $\Delta \Delta \mathrm{CT}</$ sup $>$ Method." Methods 25(4): 402408.

Najeeb, S., F. A. Sheikh, M. A. Ahangar and N. A. Teli (2011). "Popularization of sweet corn (Zea mays L. Saccharata) under temperate conditions to boost the socioeconomic conditions." Maize Genetic Cooperation Newsletter 85.

Obana, Y., D. Omoto, C. Kato, K. Matsumoto, Y. Nagai, I. H. Kavakli, S. Hamada, G. E. Edwards, T. W. Okita and H. Matsui (2006). "Enhanced turnover of transitory starch by expression of upregulated ADP-glucose pyrophosphorylases in Arabidopsis thaliana." Plant science 170(1): 111.

Rosti, S. and K. Denyer (2007). "Two paralogous genes encoding small subunits of ADP-glucose pyrophosphorylase in maize, Bt2 and L2, replace the single alternatively spliced gene found in other cereal species." J. Molecular Evolution 65(3): 316-327.

Russell, D. A., D. L. DeBoer, D. M. Stark, J. Preiss and M. E. Fromm (1993). "Plastid targeting of E. coli $\hat{\mathrm{I}}^{2}$-glucuronidase and ADP-glucose pyrophosphorylase in maize (Zea mays L.) cells." Plant cell reports 13(1): 24-27.

Shang-Jing, G. U. O., L. I. Jia-Rui, Q. Wei-Hua and X.-S. Zhang (2006). "Analysis of amylose accumulation during seed development in maize." Acta Genetica Sinica 33(11): 10141019.

Smidansky, E. D., M. Clancy, F. D. Meyer, S. P. Lanning, N. K. Blake, L. E. Talbert and M. J. Giroux (2002). "Enhanced ADP-glucose pyrophosphorylase activity in wheat endosperm increases seed yield." Proceedings of the National Academy of Sciences 99(3): 17241729.

Smidansky, E. D., J. M. Martin, C. L. Hannah, A. M. Fischer and M. J. Giroux (2003). "Seed yield and plant biomass increases in rice are conferred by deregulation of endosperm ADP-glucose pyrophosphorylase." Planta 216(4): 656-664.

Zhang, H. Y., S. T. Dong, R. Q. Gao and Y. Q. Li (2007). "Comparison of starch synthesis and related enzyme activities in developing grains among different types of maize." Zhi wu sheng li yu fen zi sheng wu xue xue bao=J. Plant Physiology and Molecular Biology 33(1): 25-32.

Znidarcic (2012). "Performance and characterization of five sweet corn cultivars as influenced by soil properties." International J. Food, Agriculture and Environment 10(1): 495-500. 